\title{
Factor that Influence on Ultra-Orthodox Jewish Mothers' Service Satisfaction with Obstetric Care in Israeli Public Hospitals
}

Iris gertner moryossef ( $\square$ irisge@hadassah.ac.il )

\section{Research article}

Keywords: Obstetric care satisfaction, Interpersonal dimension, Technical 97 dimension, Physical environment

Posted Date: July 6th, 2020

DOI: https://doi.org/10.21203/rs.3.rs-17799/v1

License: (c) (1) This work is licensed under a Creative Commons Attribution 4.0 International License. Read Full License 


\section{Factor that Influence on Ultra-Orthodox Jewish Mothers' \\ Hospitals}

Dr. Iris Gertner Moryossef 6

Author Affiliation: $\quad 7$

Hadassah Academic College, Jerusalem, Israel 8

Correspondence to: Dr. Iris Gertner Moryossef 9

irisge@hac.ac.il 10

Dr. Keren Mazuz - Corresponding Author 12

Author Affiliation 13

Hadassah Academic College, Jerusalem, Israel 14

kerenma@hac.ac.il 15

$\begin{array}{ll}\text { Abstract } & 18\end{array}$

The Ultra-Orthodox sector is a uniquely conservative and closed community 19 within Israeli society, which makes up 8-11\% of the population of Israel. The 20

Ultra-Orthodox live in separate neighborhoods that constitute closed cultural 21 quarters with little interaction with the non-orthodox society. Within these 22 neighborhoods, they maintain their traditional lifestyle, which adheres to strict, $\quad 23$ Torah-based Jewish law. Observance of Jewish laws and customs is closely 24 monitored and access to the internet and the general media is limited, keeping 25 the exposure to undesired contents at the minimum. 26

$\begin{array}{ll}\text { Religious law observance includes modest dress codes, complete separation } & 27\end{array}$ between male and female that begins in early childhood, and strong family 28 values, including marrying young and aspiring to form a big, close-knit family $\quad 29$ unified around the traditions of the community. The men in the Ultra-Orthodox 30 
society dedicate themselves to full-time religious studies in specialized

institutions (the Kollel), while the women oversee the family income, children's

Since $99 \%$ of childbirths take place in hospitals (the general homebirth rate in

Israel is smaller than $1 \%)$ and due to the generous grant (3,0oo dollars) that childbirth experience, including with the caregivers and the delivery rooms. The underlying assumption is that the mother's satisfaction is essential to her loyalty when choosing hospitals in her future labors. We also examined whether the satisfaction.

This study was composed of two phases: in the first phase we conducted 
The questionnaires were based on the former questionnaires from the scholar

evaluate obstetrics' evaluation among mothers after childbirth. 65

We conducted the survey in April-October 2018 in infant healthcare centers, $\quad 66$

which provide healthcare services to the mother and her infant (ages o-2 years $\quad 67$

$\begin{array}{ll}\text { old) like vaccination a weight measurement. } & 68\end{array}$

\section{Results:}

Results show three dimensions of factors that have significant influence on

UOJM's satisfaction. The first is he Interpersonal dimension, which refers to the 72

attitude of service givers and their interaction with the mother; the second

dimension is the Physical surroundings, including sanitation and privacy during

childbirth; and the third dimension is the Technical dimension, which includes

emergency and anesthesia equipment.

The mothers were highly satisfied with all three dimensions, but the

interpersonal dimension was the strongest predictor of satisfaction $\left(\mathbf{1 7 . 6 3}^{* *}\right)$,

compared to the Physical and O dimension (14.23**, $\left.13.36^{* *}\right)$. On a scale of $1-5$,

the mothers were highly satisfied with the following factors: : 1) privacy during 80

delivery (4.49); 2) professional conduct of the staff; and 3) waiting time for 81

personnel $(4.17,4.20)$.

In contrast, the mothers were less satisfied with the following factors: 1)

consulting with the mother; and 2) giving her enough information (these factors

relate to the interpersonal dimension) (2.79 and 2.81 respectively).

No correlation was found between satisfaction and sociodemographic variables or 86 previous childbirths.

\section{Conclusions}

The results point to the importance of Interpersonal, Physical and Technical 
confidence among UOJM and increase their loyalty to a specific hospital in future 95 $\begin{array}{ll}\text { deliveries. } & 96\end{array}$

Key words: Obstetric care satisfaction, Interpersonal dimension, Technical 97 dimension, Physical environment. 98

\section{Background}

Ultra-Orthodox Jews in Israel (who made up 8\%-11\% of the Israeli population in 100 2018) live in closed neighborhoods and adhere to traditions and customs based 101 on Jewish law (the Torah and subsequent writings). They avoid accessing the 102 internet and wear modest clothes. Ultra-Orthodox children acquire the 103 knowledge and motivation to continue the strictest enforcement of Jewish law. 104 Men enter a regime of full-time study of religious Jewish texts at 18 years old ([1] 105 ;[2]). While the men spend their days studying, the women take charge of the 106 house, including income and children's education. The high fertility rate among this population (three times that of the non-Orthodox) is based on Genesis (1:28: )"Be fruitful and multiply and replenish the earth and subdue it" ([3];[4]). 109 Within the Ultra-Orthodox society, having a baby is not only a physical and 110 biological experience but also a fulfillment of a spiritual purpose, since the core experience in this world, in their view, is bringing a soul into the world ([5];[6]). Motivated by the high grant from the Ministry of Health for each delivery (3,000 dollars), Israeli hospitals make extreme efforts to bring in more Orthodox women. Their efforts to encourage women to use their services throughout their deliveries include Kosher food, separation between men and women, a synagogue on premises, or taking care for the young children .. ([2];[4]).

Prior studies that focused on healthcare service used questionnaires to evaluate empathy toward the mother and her companion. The second parameter is the service giver in the room, sanitation of the environment, a private space given to the mother, and the team - organization. The third parameter determining the 
emergency equipment used during the delivery. All three parameters are

\section{Methodology}

\section{The Aim of the study}

The aim of this study is to evaluate the cultural factors that affect UOJM's

\section{The study area and study design}

The study population is UOJM who had vaginal deliveries (no caesarean or other

In each city we approached about 40-50 UOJM. We had face to face interviews with them in the explanatory stage as well as in the second phase, during which we delivered the questionnaires. The study instrument was self-administered questionnaires, designed, validated and pretested for the purpose of a large cross-

The participating mothers had to fill in the questionnaires by themselves. The 
while she completed it. We used 5 students for each of the four cities, 20 students

all together. Satisfaction with one of the aspects was defined as the proportion of

mothers who had chosen a mark of 4 or 5 with all the variables under this aspect

of care.

Data collection, data instrument

The journey of the study was conducted using mixed methodologies in two

Phase 1

Qualitative face to face interview
Phase 2

Quantitative questionnaire

Table 1: The research phases

\begin{tabular}{|l|l|l|}
\hline Step & Purpose & Number \\
\hline $\begin{array}{l}\text { Qualitative } \\
\text { interviews }\end{array}$ & $\begin{array}{l}\text { Identifying main factors that have significant } \\
\text { influence on mothers' evaluation of obstetric care } \\
\text { service. }\end{array}$ & 36 UJOM \\
\hline $\begin{array}{l}\text { Quantitative } \\
\text { questionnaire } \\
\text { Ranking the influence of the significant factors on the } \\
\text { mothers' evaluation. }\end{array}$ & 161 UJOM \\
\hline $\begin{array}{l}\text { Quantitative } \\
\text { questionnaire } \\
\text { quantitative } \\
\text { (Physionnaire }\end{array}$ & $\begin{array}{l}\text { Identifying correlations between factors and } \\
\text { sociodemographic variables. }\end{array}$ & 161 UJOM \\
\hline $\begin{array}{l}\text { Quantitative } \\
\text { questionnaire }\end{array}$ & Determining predictors of mothers' satisfaction. & 161 UJOM \\
\hline
\end{tabular}

Explanatory phase: At this first phase we aimed to identify the main factors that influence mothers' satisfaction with childbirth services. We used face-to-face

interviews with UJOM, asking them open questions such as "what is important to you?" We also asked the mothers about their prior expectations, and what aspects of the Technical procedures (equipment, anaesthesia and alternative medicine), the Physical surrounding (sanitation of the facilities, privacy, team work and 
or empathy by the midwives) they were pleased with. Based on phase one, we

In the second phase we used close ended questionnaires to evaluate the

The questionnaires were given to each mother after explaining the academic

Data analysis was performed using SPSS v.18.o (IBM Corp., Armonk, NY, USA).

\section{Ethical considerations}

The study proposal was approved by the Internal Ethical Review Board of 


\section{Results}

\section{Dimensions of mother's satisfaction:}

Using an explanatory study among 36 mothers we interviewed them

in related the main factors influence their satisfaction in the delivery room.

The mothers mentioned that interpersonal interaction as well as the

Using factor analysis, we categorized the items into the following

For each item, the mothers marked their satisfaction using a 5-point

Table 2: Factor analysis influence the mother's satisfaction 


\section{[1] Technical dimension}

1. Process and medical facilities in the room (drugs, equipment, etc.) $\quad \mathbf{0 . 6 7}$

2. Equipment for emergency

3. Availability of anesthesia equipment

4. Alternative medicine and therapy during delivery

[2] Physical environment

5. Sanitary facilities (water, toilets, bathrooms) in the room

6. Privacy maintained by the health staff during the care

0.93

7. Organizational teamwork

8. Attendance and accessibility of the service giver in the room

\section{[3] Interpersonal dimension of care}

0.74

9. Professional training, literacy, the nurses and midwives

10. Waiting time and responsiveness of the personnel

11. Listening and attending to the mother's wishes

12. The quality of the service and treatment

13. Kindness and attitude of the personnel to the mother as an individual

14. Kindness \& courtesy of the personnel to mother's accompanying person

15. Consulting with the mother before interfering

16.Information was given to the mother during procedure

17. Empathy and consideration of the nurses and midwives

Demographic characteristics of the sample:

Table 3: Socio-demographic characteristics of the UOJM 
Table no 3 shows the representative distribution of the sample related to age, income, education and previous childbirths.

\begin{tabular}{|c|c|}
\hline 242 & Variables \\
\hline Agę4(years) & $18-24$ \\
\hline 244 & $25-34$ \\
\hline 245 & $35+$ \\
\hline \multirow[t]{2}{*}{ Edw̧4ation } & Low level of education (high scho \\
\hline & High level of education ( $1^{\text {st }}$ degree \\
\hline \multirow[t]{2}{*}{ Primiparity } & Nulliparous new mother for the fi \\
\hline & Parous (1-4 children include the $n$ \\
\hline 250 & $\begin{array}{l}\text { Multiparous (more than } 4 \text { childre } \\
\text { the new baby) }\end{array}$ \\
\hline \multirow{3}{*}{$\begin{array}{l}\text { Income of } \\
252 \\
\text { the } \\
253 \\
\text { household } \\
254\end{array}$} & Lower than the average income \\
\hline & Average income \\
\hline & Higher than the average income \\
\hline 255 & Total \\
\hline
\end{tabular}

most satisfied factors were

\section{Satisfaction in general} items and dimensions

Mothers' satisfaction in general was high (3.67) regardless of age, income, education, and previous birth (see Table 4). Th privacy during delivery (4.49), waiting time (4.17) and professionalism and literacy of the nurses and midwives (4.20).

Dissatisfaction was found in consultation with the mother (2.79); Information that is given to the mother (2.81) and alternative medicine treatment (mothers' satisfaction was only 1.52). Other items, such as work organization, sanitary facilities, kindness and empathy towards the mother and her companion received a median score (3.52-3.88)

Table 4: Mean and Std. Deviation of the item's satisfaction
256

257

258

259

260

261

262

263

264

\begin{tabular}{|l|l|l|}
\hline Dimension and items & Satisfaction & $\begin{array}{l}\text { Std. } \\
\text { Deviation }\end{array}$ \\
\hline Technical dimension & & 1.98 \\
\hline $\begin{array}{l}\text { Process and medical facilities in the room } \\
\text { (drugs, equipment, etc.) }\end{array}$ & 3.67 & \\
\hline
\end{tabular}




\begin{tabular}{|c|c|c|}
\hline Equipment of emergency & 3.65 & 1.86 \\
\hline Availability of anesthesia equipment & 3.74 & 1.90 \\
\hline $\begin{array}{l}\text { Alternative medicine and therapy during } \\
\text { delivery }\end{array}$ & 1.22 & 1.02 \\
\hline \multicolumn{3}{|l|}{ Physical dimension } \\
\hline $\begin{array}{l}\text { Sanitary facilities (water, toilets, bathrooms) in } \\
\text { the room }\end{array}$ & 3.67 & 1.22 \\
\hline $\begin{array}{l}\text { Privacy maintained by the health staff during } \\
\text { care }\end{array}$ & 4.49 & 3.51 \\
\hline Organizational, teamwork & 3.45 & 1.32 \\
\hline $\begin{array}{l}\text { Attendance and accessibility of the service giver } \\
\text { in the room }\end{array}$ & 3.67 & 1.22 \\
\hline \multicolumn{3}{|l|}{ Interpersonal dimension of care } \\
\hline $\begin{array}{l}\text { Professional training, literacy of the nurses and } \\
\text { midwives }\end{array}$ & 4.70 & 1.04 \\
\hline $\begin{array}{l}\text { Waiting time and responsiveness of the } \\
\text { personnel }\end{array}$ & 4.47 & 2.53 \\
\hline Listening and attending to the mother's wishes & 2.20 & 1.12 \\
\hline The quality of the service and treatment & 3.77 & 1.18 \\
\hline $\begin{array}{l}\text { Kindness and attitude of the personnel to the } \\
\text { mother as an individual }\end{array}$ & 3.84 & 1.25 \\
\hline $\begin{array}{l}\text { Kindness \& courtesy of the personnel to } \\
\text { mother's accompanying person }\end{array}$ & 3.52 & 1.78 \\
\hline Consulting with the mother before interfering & 2.29 & 1.23 \\
\hline $\begin{array}{l}\text { Information was given to the mother during } \\
\text { procedure }\end{array}$ & 2.21 & 1.45 \\
\hline $\begin{array}{l}\text { Empathy and consideration of the nurses and } \\
\text { midwives }\end{array}$ & 3.88 & 1.33 \\
\hline
\end{tabular}


Correlation between mother's satisfaction with

To find a significant correlation between sociodemographic variables,

To find any correlation between items' dimensions and demographic

Table 5: Correlation between dimensions' satisfaction and

\begin{tabular}{|l|l|l|l|l|}
\hline Dimension and items & $\begin{array}{l}\text { Age at } \\
\text { birth }\end{array}$ & $\begin{array}{l}\text { Educat } \\
\text { ion }\end{array}$ & $\begin{array}{l}\text { Inco } \\
\text { me }\end{array}$ & $\begin{array}{l}\text { Previous } \\
\text { childbirth }\end{array}$ \\
\hline \multicolumn{5}{|l|}{ Technical dimension } \\
$\begin{array}{l}\text { Process and medical facilities in } \\
\text { the room (drugs, equipment, etc.) }\end{array}$ & .02 & .18 & -.06 & -.01 \\
\hline $\begin{array}{l}\text { Equipment for emergency } \\
\text { Availability of anesthesia } \\
\text { equipment }\end{array}$ & -.16 & .04 & -.22 & -.20 \\
\hline
\end{tabular}




\begin{tabular}{|c|c|c|c|c|}
\hline $\begin{array}{l}\text { Alternative medicine and therapy } \\
\text { during delivery }\end{array}$ & .02 & .04 & .06 & -.06 \\
\hline \multicolumn{5}{|l|}{ Physical environment } \\
\hline $\begin{array}{l}\text { Sanitary facilities (water, toilets, } \\
\text { bathrooms) in the room }\end{array}$ & .01 & .11 & -.01 & -.07 \\
\hline $\begin{array}{l}\text { Privacy maintained by the health } \\
\text { staff during the care }\end{array}$ & .17 & .17 & .12 & .17 \\
\hline Organizational, teamwork & .05 & .07 & -.07 & .03 \\
\hline $\begin{array}{l}\text { Attendance and accessibility of } \\
\text { the service- giver in the room }\end{array}$ & -.01 & .09 & -.08 & -.12 \\
\hline \multicolumn{5}{|c|}{ Interpersonal dimension of care } \\
\hline $\begin{array}{l}\text { Professional training, literacy the } \\
\text { nurses and midwives }\end{array}$ & .01 & .23 & .11 & .05 \\
\hline $\begin{array}{l}\text { Waiting time and responsiveness } \\
\text { of the personnel }\end{array}$ & -.11 & -.04 & -.03 & -.05 \\
\hline $\begin{array}{l}\text { Listening and attending to the } \\
\text { mother's wishes }\end{array}$ & .09 & .11 & -.01 & -.04 \\
\hline $\begin{array}{l}\text { The quality of the service and } \\
\text { treatment }\end{array}$ & .03 & .13 & .04 & -.12 \\
\hline $\begin{array}{l}\text { Kindness and attitude of the } \\
\text { personnel to the mother as an } \\
\text { individual }\end{array}$ & .06 & .05 & .02 & .14 \\
\hline $\begin{array}{l}\text { Kindness and attitude of the } \\
\text { personnel to the mother as an } \\
\text { individual }\end{array}$ & .11 & .11 & .03 & -.02 \\
\hline $\begin{array}{l}\text { Consulting with the mother } \\
\text { before interfering }\end{array}$ & -.04 & .20 & -.02 & -.01 \\
\hline
\end{tabular}




\begin{tabular}{|l|l|l|l|l|}
\hline $\begin{array}{l}\text { Information was given to the } \\
\text { mother during procedure }\end{array}$ & -.22 & .19 & .02 & -.11 \\
\hline $\begin{array}{l}\text { Empathy and consideration of } \\
\text { the nurses and midwives }\end{array}$ & -.04 & .20 & -.06 & .12 \\
\hline
\end{tabular}

${ }^{*} \mathrm{p}<0.05{ }^{* *} \mathrm{P}<0.01$

Table 6: Correlation between items' satisfaction and demographic 286 variables

\begin{tabular}{|l|l|l|l|l|}
\hline $\begin{array}{l}\text { Dimension and } \\
\text { items }\end{array}$ & $\begin{array}{l}\text { Age in } \\
\text { birth }\end{array}$ & $\begin{array}{l}\text { Educatio } \\
\mathbf{n}\end{array}$ & Income & $\begin{array}{l}\text { Previous } \\
\text { child } \\
\text { birth }\end{array}$ \\
\hline Technical dimension & -.07 & -.05 & .11 & -.14 \\
\hline $\begin{array}{l}\text { Physical } \\
\text { environment }\end{array}$ & .01 & -.09 & .07 & .08 \\
\hline $\begin{array}{l}\text { Interpersonal } \\
\text { dimension }\end{array}$ & -.15 & .19 & .19 & -.11 \\
\hline Mean satisfaction & -.07 & -.04 & .18 & -.07 \\
\hline
\end{tabular}

${ }^{*} \mathrm{p}<0.05{ }^{* *} \mathrm{P}<0.01$

Predictors of mother's satisfaction:

Linear regression including service's dimensions:

Linear multiple regression was conducted to define significant

dimensions predicting mother's satisfaction (see Table 7 ). The

regression t explained $91 \%$ of the satisfaction variance $(\mathrm{F}(3,147)$

$=146.62, \mathrm{p}<0.001$ )

$\mathrm{Al}$ three aspects had high correlation to mother's average satisfaction,

but the interpersonal dimension had the high score $(\beta=.57)$.

Table 7: Linear multiple regression of dimensions' satisfaction 


\begin{tabular}{|l|l|l|l|l|}
\hline Dimensions & \multicolumn{1}{|l|}{$\begin{array}{l}\text { Std. } \\
\text { Error }\end{array}$} & Beta \\
\cline { 1 - 4 } $\begin{array}{l}\text { Interpersonal } \\
\text { dimension }\end{array}$ & $17.63^{* *}$ & .594 & .03 & .57 \\
\hline $\begin{array}{l}\text { Physical } \\
\text { environment }\end{array}$ & $14.23^{* *}$ & .474 & .02 & .48 \\
\hline \begin{tabular}{l} 
Technical dimension \\
\hline
\end{tabular} & $13.36^{* *}$ & .437 & .02 & .43 \\
\hline
\end{tabular}

${ }^{*} \mathrm{p}<0.05{ }^{* *} \mathrm{P}<0.01$

Linear regression with all variables:

Linear regression between UOJM mothers' satisfaction and all

variables (service dimensions and demographic variables):

The regression analysis was found to be significant $[\mathrm{F}(7,117)=98.17$,

$\mathrm{p}<0.001]$ and explained $93 \%$ of the satisfaction' s variance. As seen in

Table 8, the demographic variables (age, income, education, and

previous childbirths) were not found to be significant predictors of

the UOJMs' satisfaction. ( $\beta=-.05)$.

As seen in the results, interpersonal dimension is the main predictor influence religious UOJM's satisfaction $(\beta=.47)$. Based on linear regression, service's technical and physical surrounding predict

Table 8: Linear multiple regression of factors influences mothers' 


\begin{tabular}{|c|c|c|c|c|}
\hline Dimensions & $\mathbf{t}$ & $\mathbf{B}$ & $\begin{array}{l}\text { Std. } \\
\text { Error }\end{array}$ & Beta \\
\hline $\begin{array}{l}\text { Interpersonal } \\
\text { dimension }\end{array}$ & $23.81^{* *}$ & .62 & .02 & .47 \\
\hline $\begin{array}{l}\text { Physical } \\
\text { environment }\end{array}$ & $11.78^{* *}$ & .37 & .03 & .27 \\
\hline $\begin{array}{l}\text { Technical } \\
\text { dimension }\end{array}$ & $9.74^{* *}$ & .35 & .02 & .21 \\
\hline $\begin{array}{l}\text { Age when giving } \\
\text { birth }\end{array}$ & 1.42 & .06 & .04 & .05 \\
\hline Education & -1.09 & -.04 & .04 & -.05 \\
\hline Income & -.67 & -.02 & .03 & -.02 \\
\hline $\begin{array}{l}\text { Previous } \\
\text { childbirths }\end{array}$ & 1.33 & .05 & .03 & .04 \\
\hline
\end{tabular}

Discussion

In general: The high childbirth rate among UOJM in Israel (more than six

children per family compared to a national average of 2.9 children) and the fact that more than $99 \%$ of deliveries take place in public hospitals make this an exciting and motivating research, as it studies the factors that influence UOJM's satisfaction during childbirth in public hospitals. The Ultra-Orthodox Jewish community holds a traditional and conservative lifestyle with codes of modesty and resistance to the internet and social networks, relying on word of mouth communication ([3]; [6]). Understanding the central factors that play a role in 
ability to predict their obstetrics service satisfaction may encourage maternity

Dimensions of satisfaction: The factors that influence UOJM's satisfaction the medical staff, and privacy given to the mother; and the Technical dimension

The interpersonal dimension: within this dimension, the high level of 
The Physical surrounding dimension: All items in the Physical dimension

The Technical dimension: although birthing women use conventional

Sociodemographic variables: UOJM's satisfaction with all three dimensions

\section{Research limitations}

The research has several limitations that arise mainly from the type of population examined. The first limitation concerns the small number of participants, 
terms of the medical procedure, this study sample examined only vaginal

\section{Conclusions}

Although satisfaction with childbirth services is multidimensional, the most

The study's findings are compatible with those of other studies ([34]; [35]; [36]), procedure.

Another way to increase mother's satisfaction is to highlight the personal to provide an outstanding service. Asking each mother before and during 


\section{Declarations}

Ethics approval and consent to participate:

The ethical approval was granted by the Internal ethical review

The manuscript does not include any individual person's data; hence

consumerism

to publish is not applicable.

The participants confirm their consent by written

Consent to publish

The manuscript does not include any individual person's data; hence

to publish is not applicable.

\section{Availability of data and materials:}

The data sets generated during and/or analyzed during the current

study are available from the corresponding author on reasonable

The real database supporting the conclusions of this article is

available in the Israeli:

https://main.knesset.gov.il/pages/default.aspx

The data supporting the Ultra-Orthodox Jews Haredim in Israel

population are available in the Central Breuer of Statistic of Israel

\section{Competing interests}

The authors declare that they have no competing interests. 
Funding:

This project was funded by the Hadassah Academic College. The

funder had no role in the study design, data collection and analysis or

\section{Authors' contributions}

IGM designed the study and drafted the manuscript, KM helped

design the study, assisted with writing the paper, and, and performed

\section{Acknowledgments:}

We would like to extend our deepest gratitude to the Hadassah

Academic College in Jerusalem for financing this research.

Our appreciation goes to the data collectors and supervisors who

\section{References:}

1. Engelsman, Shimrit Prins; HUSS, Ephrat; CWIKEL, Julie. How 
2. Beck, S. E., \& Goldberg, E. K. (1996). Jewish beliefs, values, and practices: Implications for culturally sensitive nursing care.

Advanced Practice Nursing Quarterly, 2, 15-22.

3. Lev-On, Azi; SHAHAR, Rivka Neriya-Ben. A forum of their women who browse designated closed fora. First Monday, 2011, 16.

https://ojphi.org/ojs/index.php/fm/article/view/3228

4. Witztum, E. (2002). Cross-cultural encounters between care

providers: Rabbis' referral letters to a psychiatric clinic in Israel.

Social Science and Medicine, 55, 1309-1323.

https://www.sciencedirect.com/science/article/abs/pii/S0277953601002787

5. (CALLISTER, Lynn Clark; SEMENIC, Sonia; FOSTER, Joyce

Cameron. Cultural and spiritual meanings of childbirth:

Orthodox Jewish and Mormon women. Journal of Holistic

Nursing, 1999, 17.3: 280-295

6. Research Malach, G., Cohen, D., \& H. Zicherman: A Master

7. Christiaens, W., Van De Velde, S., \& P. Bracke: Pregnant Women's

Hypothesis. Women \& Health.2011 (51); 220-239

https://www.tandfonline.com/doi/abs/10.1080/03630242.2011.5

8. Chatzoglou, P., Chatzoudes, D., Vraimaki, E., \& A. Diamantidis : 
Service Centers (CSCs) of Greece. International Journal of

Productivity and Performance Management. 2013(62): 583-605. 520

https://www.emerald.com/insight/content/doi/10.1108/IJPP

9. Goodman, P., Mackey, M.C., \& A. S .Tavakoli: Factors Related to

Childbirth Satisfaction. Journal of Advanced Nursing. 2004(46):

https://onlinelibrary.wiley.com/doi/abs/10.1111/j.1365-

10. Lonner, W. J., Berry, J. W., \& G.H. Hofstede: Culture's 1980.

11. OLIVER, Richard L. Satisfaction: A behavioral perspective on the 2014 .

https://www.taylorfrancis.com/books/9781315700892

12.TAYELGN, Azmeraw; ZEGEYE, Desalegn T.; KEBEDE, Yigzaw.

13.Aldridge, S., \& Rowley, J. (1998). Measuring customer 
http://www.adolphus.me.uk/emx/surveys/cus_satis_files/p19 549

7.htm

14.Attkisson, C. C., \& Zwick, R. (1982). The Client Satisfaction

Questionnaire: Psychometric properties and correlations with

service utilization and psychotherapy outcome. Evaluation and

http://www.adolphus.me.uk/emx/surveys/cus_satis_files/p197.ht

15.TADESSE, Biniyam Haile; BAYOU, Negalign Birhanu; NEBEB,

Gebeyehu Tsega. Mothers' Satisfaction with Institutional

Delivery Service in Public Health Facilities of Omo Nada

District, Jimma Zone. Clinical Medicine Research, 2017, 6.1: 2330.

https://s3.amazonaws.com/academia.edu.documents/60688502/1

16.ZEITHAML, Valarie A., et al. Delivering quality service:

Balancing customer perceptions and expectations. Simon and

Schuster, 1990:35-134

https://books.google.co.il/books?hl=iw\&lr=\&id=RWPMYP7-

17.HOMBURG, Christian; GIERING, Annette. Personal 
https://onlinelibrary.wiley.com/doi/abs/10.1002/1520- 576

6793(200101)18:1\%3C43::AID-MAR3\%3E3.0.CO;2-I 577

18. SENARATH, Upul; FERNANDO, Dulitha N.; RODRIGO,

Ishani. Factors determining client satisfaction with hospital-based

perinatal care in Sri Lanka. Tropical Medicine \& International

Health, 2006, 11.9: 1442-1451.

https://onlinelibrary.wiley.com/doi/full/10.1111/j.1365-

19.CHOI, Kui-Son, et al. The service quality dimensions and patient

satisfaction relationships in South Korea: comparisons across

https://www.emerald.com/insight/content/doi/10.1108/0887604

20. SIKA AVORTRI, Gertrude; BEKE, Andy; ABEKAH-

NKRUMAH, Gordon. Predictors of satisfaction with child birth

https://www.emerald.com/insight/content/doi/10.1108/0952686

21.MATEJIĆ, Bojana, et al. Maternal satisfaction with organized

https://bmcpregnancychildbirth.biomedcentral.com/articles/10.11 
22. BRYSON, John M.; CROSBY, Barbara C.; BLOOMBERG, Laura. 606 Public value governance: Moving beyond traditional public administration and the new public management. Public 608 administration review, 2014, 74.4: 445-456.

23. CHANG, Ching-Sheng; CHEN, Su-Yueh; LAN, Yi-Ting. Service

https://bmchealthservres.biomedcentral.com/articles/10.1186/14

24. SRIVASTAVA, Aradhana, et al. Determinants of women's from developing countries. BMC pregnancy and childbirth, 2015, 15.1: 97 .

https://bmcpregnancychildbirth.biomedcentral.com/articles/10

25. D'AMBRUOSO, Lucia; ABBEY, Mercy; HUSSEIN, Julia. Please 626 understand when I cry out in pain: women's accounts of maternity services during labour and delivery in Ghana. BMC public health, 2005, 5.1: 140. 
26. HAUCK, Yvonne, et al. The influence of childbirth expectations

on Western Australian women's perceptions of their birth

experience. Midwifery, 2007, 23.3: 235-247.

https://www.sciencedirect.com/science/article/abs/pii/So266613

27. DREW, N. C.; SALMON, P.; WEBB, L. Mothers', midwives' and obstetricians' views on the features of obstetric care which influence satisfaction with childbirth. BJOG: An International

Muñoz-Sellés, E., Vallès-Segalés, A., \& Goberna-Tricas, J. (2013).

28. FERRER, Ma Belén Conesa, et al. Comparative study

29. SHAHAR, Rivka Neriya-Ben; LEV-ON, Azi. Gender, religion 
environments. International Journal of Communication, 2011, 5: 661 21.

https://ijoc.org/index.php/ijoc/article/view/843

30. SHATTELL, Mona. Nurse-patient interaction: a review of the

literature. Journal of clinical nursing, 2004, 13.6: 714-722.

31.ROTER, Debra, et al. The effects of a continuing medical education programme in interpersonal communication skills on doctor practice and patient satisfaction in Trinidad and Tobago. Medical education, 1998, 32.2: 181-189.

https://onlinelibrary.wiley.com/doi/abs/10.1046/j.1365-

32. HOMBURG, Christian; GIERING, Annette. Personal

characteristics as moderators of the relationship between customer

33. GREEN, Josephine M.; COUPLAND, Vanessa A.; KITZINGER, 
34. KRUPAT, Edward, et al. When physicians and patients

think alike: patient-centered beliefs and their impact on

satisfaction and trust. Journal of Family Practice, 2001, 50.12:

693 1057-1063

https://go.galegroup.com/ps/anonymous?id=GALE\%7CA81136

695

237\&sid=googleScholar\&v=2.1\&it=r\&linkaccess=abs\&issn=009

696

$43509 \& \mathrm{p}=\mathrm{AONE} \& \mathrm{sw}=\mathrm{w}$.

35 .

Ali M. How patients perceive healthcare services: A case

of Ayub Teaching hospital, Abbottabad-Pakistan. SERV service

Management. 2018 Jan 2;11(1):52-9.

36. Clemes MD, Ozanne LK, Laurensen WL. Patients' 